\title{
AKTIVITAS FISIK DENGAN TINGKAT HIPERTENSI DI PUSKESMAS KOTA PALEMBANG
}

\author{
THE CORRELATION BETWEEN PHYSICAL ACTIVITY AND HYPERTENSION \\ LEVEL AT PUBLIC HEALTH CENTER PALEMBANG \\ Lily Marleni ${ }^{1}$, Abdul Syafei,Mega Thia Purnama Sari \\ ${ }^{1}$ STIK Siti Khadijah Palembang, Sumatera Selatan, Indonesia \\ (penulis korespondensi: lilyasheeqa@gmail.com)
}

\author{
Info Artikel: Diterima: 07 Maret $2020 \quad$ Revisi: 22 Mei $2020 \quad$ Disetujui: 17 Juni 2020
}

\begin{abstract}
ABSTRAK
Latar Belakang: Hipertensi atau yang sering disebut darah tinggi merupakan salah satu penyakit tidak menular yang merupakan masalah di Indonesia. Hipertensi adalah keadaan dimana seseorang dinyatakan mengalami peningkatan tekanan darah di atas batas normal. Penelitian ini bertujuan untuk menganalisis pengaruh aktivitas Fisik dengan Tingkat Hipertensi di Puskesmas Merdeka Palembang Metode: Penelitian ini merupakan observasional analitik dengan desain potong lintang. Penelitian ini dilakukan pada tanggal 11 - 21 Juni 2019. Jumlah sampel penelitian sebanyak 88 responden.

Hasil: Penelitian ini mendapatkan hasil bahwa lebih banyak responden dengan aktivitas fisik ringan dengan hasil sebanyak 51 responden $(58,0 \%)$, dan responden yang memiliki hipertensi ringan dengan hasil sebanyak 69 responden $(78,4 \%)$. Hasil penelitian di dapatkan bahwa ada pengaruh antara aktivitas fisik dengan tingkat hipertensi dengan $p$ value 0,0005 .

Kesimpulan : Pada penelitian ini disimpulkan bahwa kebanyakan dari penderita ini melakukan aktivitas fisik ringan. Bentuk aktivitas fisik yang biasa dilakukan responden adalah dengan kegiatan seperti olahraga secara ringan yang sebenernya merupakan kegiatan sehari-hari yang biasa dilakukan dirumah seperti menyapu lantai, berjalan kaki, bersepeda, dan lain-lain untuk mengurangi peningkatan tekanan darah.
\end{abstract}

Kata Kunci: Aktivitas Fisik, Tingkat Hipertensi

\section{ABSTRACT}

Background: Hypertension or often called high blood pressure is one non-communicable diseases which are a problem in Indonesia. Hypertension is a condition where a person is declared to have an increase in blood pressure above the normal limit. Riskesdas (2018) shows the prevalence of measurement results blood pressure, hypertension rose from $25.8 \%$ to $34.1 \%$. The aim of this study is to know the relationship between Physical Activity and The Level of Hypertension in Merdeka Primary Health Center Palembang in 2019.

Methods: This research used quantitative methods the research design used was descriptive analytic with cross sectional approach. This research was done on 11-21 June 2019. The research sample was 88 respondents. $T$

Results: The results of this research that more respondents with mild physical activity with results as many as 51 respondents (58.0\%), and respondents who had mild hypertension with the results of 69 respondents (78.4\%).

Conclusion: In this study it was concluded that most of these sufferers engage in mild physical activity. The form of physical activity that is usually done by respondents is with activities such as light exercise which is actually a daily activity that is usually done at home such as sweeping the floor, walking, cycling, and others to reduce the increase in blood pressure.

Keywords: Physical Activity, Hypertention Level 


\section{PENDAHULUAN}

Hipertensi merupakan masalah kesehatan yang terjadi seluruh dunia. Berdasarkan data Word Health Organization (WHO) tahun 2013, menyatakan bahwa terjadi peningkatan jumlah orang yang menderita hipertensi dari 600 juta pada tahun 1980 menjadi 1 miliar pada tahun 2008. Di perkirakan akan terus meningkat pada tahun 2020 sekitar 1,56 miliar orang dewasa akan hidup dengan hipertensi. ${ }^{1}$

Hasil Riskesdas tahun 2018, menunjukkan prevalensi Penyakit Tidak Menular di Indonesia mengalami kenaikan jika dibandingkan dengan Riskesdas 2013, antara lain kanker, stroke, penyakit ginjal kronis, diabetes mellitus dan hipertensi. Prevalensi hasil pengukuran tekanan darah, hipertensi naik dari $25,8 \%$ menjadi $34,1 \%$. Berdasarkan data ${ }^{2}$, didapatkan jumlah penderita hipertensi pada tahun 2015 sebesar 204.213 kasus, pada tahun 2016 sebesar 225.305 kasus, dan pada tahun 2017 sebesar 229.365 kasus ${ }^{2}$. Menurut data yang diperoleh dari Dinas Kesehatan Kota Palembang, angka kejadian penyakit hipertensi mengalami peningkatan dari tahun ke tahun. Pada tahun 2015 sebanyak 6.892 kasus, pada tahun 2016 sebanyak 7.879 kasus, dan pada tahun 2017 sebanyak 20.884 kasus. Kasus Hipertensi paling tinggi di Puskesmas Merdeka Palembang dengan urutan ke-8 dengan jumlah $1.298)^{2}$. Berdasarkan data yang di dapatkan dari pengambilan data awal oleh peneliti di Puskesmas Merdeka Palembang, pasien hipertensi pada tahun 2018 sebanyak 1.632 kasus dan data 3 bulan terakhir pada bulan Januari-Maret tahun 2019 sebanyak 760 kasus. Dari data yang diperoleh 10 penyakit tidak menular, hipertensi berada di posisi pertama. Hasil observasi di Puskesmas Merdeka Palembang fenomena dan kasus hipertensi cukup banyak. Kunjungan pasien hipertensi di Puskesmas Merdeka Palembang paling tinggi di antara 9 penyakit tidak menular lainnya yang ada di Puskesmas Merdeka Palembang.

Faktor-faktor yang berhubungan dengan hipertensi adalah faktor genetik, umur, jenis kelamin, obesitas, asupan garam, kebiasaan merokok, dan aktivitas fisik. Aktivitas fisik merupakan segala sesuatu aktivitas yang menggerakkan fisik atau tubuh kita. Kurangnya aktivitas fisik dapat membuat orang yang cenderung mempunyai frekuensi denyut jantung yang lebih tinggi sehingga otot jantung harus bekerja lebih keras pada setiap kontraksi, makin besar dan sering otot jantung memompa maka makin besar tekanan yang dibebankan pada arteri sehingga tekanan darah akan meningkat. ${ }^{2}$ Aktivitas fisik yang baik dan rutin akan melatih otot jantung dan tahanan perifer yang dapat mencegah peningkatan hipertensi. Olahraga yang teratur dapat merangsang pelepasan hormon endorfin yang menimbulkan efek euphoria dan relaksasi otot sehingga hipertensi tidak meningkat. ${ }^{3}$

Aktivitas fisik yang teratur membantu meningkatkan efisiensi jantung secara keseluruhan. Mereka yang secara fisik aktif umumnya mempunyai tekanan darah yang lebih rendah dan lebih jarang terkena hipertensi. Mereka yang secara fisik aktif cenderung untuk mempunyai fungsi otot dan sendi yang lebih baik, karena organ-organ demikian lebih kuat dan lebih lentur. ${ }^{4}$

Berdasarkan penelitian tentang Hubungan Aktivitas Fisik Dengan Tingkat Hipertensi Di Wilayah Kerja Puskesmas Demak II terdapat ada hubungan yang signifikan antara aktifitas fisik dengan tingkat hipertensi di wilayah kerja puskesmas demak II dengan hasil nilai pvalue $0.013 .^{3}$

Sedangkan penelitian tentang Hubungan Aktivitas Fisik Dengan Tingkat Hipertensi Di Wilayah Puskesmas Bromo Medan terdapat ada hubungan yang signifikan antara aktivitas fisik dengan tingkat hipertensi. Dengan tingkat kemaknaan 95\% $(\alpha \leq 0.05)$ dan hasil diperoleh nilai pvalue 0.010 . Berdasarkan study awal pada tanggal 14 Mei 2019 terhadap 10 pasien hipertensi, didapatkan bahwa hasil prevalensi didapatkan $40 \%$ pasien telah melakukan aktifitas fisik untuk membantu menurunkan hipertensi seperti melakukan senam hipertensi. Sedangkan $60 \%$ pasien lainnya kurang atau jarang melakukan aktivitas fisik dan sering lupa mengkonsumsi obat hipertensi walaupun itu selalu diperingatkan oleh dokter. ${ }^{4}$ Maka dari itu peneliti tertarik untuk melakukan penelitian tentang Hubungan Aktivitas Fisik dengan Tingkat Hipertensi di Puskesmas Merdeka Palembang Tahun 2019.

Tujuan penelitian ini untuk mengetahui hubungan aktivitas fisik dengan hipertensi di puskesmas merdeka palembang tahun 2019. 


\section{METODE}

Desain penelitian ini menggunakan deskriptif analitik dengan pendekatan cross sectional. Populasi dalam penelitian ini adalah semua pasien hipertensi di Puskesmas Merdeka Palembang dari bulan Januari-Maret tahun 2019 berjumlah 760 orang. Teknik pengambilan sampel pada penelitian ini menggunakan accidental sampling dengan jumlah sampel yang didapatkan adalah 88 Responden. Dengan Kriteria Inklusi : pasien yang menderita hipertensi di puskesmas merdek palembang, tidak mengalami gangguan pendengaran dan dapat berkomunikasi dengan baik, pasien yang bersedia menjadi responden, kriteria Eksklusi : pasien yang mengalami komplikasi.

\section{HASIL}

Tabel.1 Aktivitas Fisik

\begin{tabular}{clcc}
\hline No & Aktivitas Fisik & Jumlah & Persentase (\%) \\
\hline 1 & Ringan & 51 & 58,0 \\
2 & Sedang & 23 & 26,1 \\
3 & Berat & 14 & 15,9 \\
\hline & Jumlah & $\mathbf{8 8}$ & $\mathbf{1 0 0}$
\end{tabular}

Berdasarkan Tabel 1. responden yang memiliki aktivitas fisik ringan sebanyak 51 responden $(58,0 \%)$ lebih banyak dibandingkan dengan responden yang memiliki aktivitas fisik sedang sebanyak 23 responden $(26,1 \%)$ dan responden yang memiliki aktivitas fisik berat sebanyak 14 responden $(15,9 \%)$.

Tabel 2. Tingkat Hipertensi

\begin{tabular}{clcc}
\hline No & Tingkat Hipertensi & Jumlah & Persentase (\%) \\
\hline 1 & Ringan & 69 & 78,4 \\
2 & Sedang & 10 & 11,4 \\
3 & Berat & 9 & 10,2 \\
\hline & Jumlah & $\mathbf{8 8}$ & $\mathbf{1 0 0}$ \\
\hline
\end{tabular}

Berdasarkan Tabel 2. responden hampir seluruhnya dalam hipertensi ringan sebanyak 69 responden $(78,4 \%)$ lebih banyak dibandingkan dengan responden dengan hipertensi sedang sebanyak 10 responden $(11,4 \%)$ dan responden dengan hipertensi berat sebanyak 9 responden $(10,2 \%)$.

Tabel 3. Hubungan Aktivitas Fisik dengam Tingkat Hipertensi

\begin{tabular}{|c|c|c|c|c|c|c|c|c|c|c|}
\hline \multirow[t]{3}{*}{ No } & \multirow{3}{*}{$\begin{array}{c}\text { Aktivitas } \\
\text { Fisik }\end{array}$} & \multicolumn{6}{|c|}{ Tingkat Hipertensi } & \multicolumn{2}{|c|}{ Jumlah } & \multirow[t]{2}{*}{$P$ value } \\
\hline & & \multicolumn{2}{|c|}{ Ringan } & \multicolumn{2}{|c|}{ Sedang } & \multicolumn{2}{|c|}{ Berat } & & & \\
\hline & & $\mathrm{n}$ & $\%$ & $\mathrm{n}$ & $\%$ & $\mathrm{n}$ & $\%$ & $\mathrm{n}$ & $\%$ & \\
\hline 1 & Ringan & 47 & 92,2 & 2 & 3,9 & 2 & 3,9 & 51 & 100 & 0,0005 \\
\hline 2 & Sedang & 15 & 65,2 & 3 & 13,0 & 5 & 21,7 & 23 & 100 & \\
\hline 3 & Berat & 7 & 50,0 & 5 & 35,7 & 2 & 14,3 & 14 & 100 & \\
\hline & Jumlah & & & & & & & 88 & 100 & \\
\hline
\end{tabular}

Didapatkan hasil hubungan dari aktivitas fisik dengan tingkat hipertensi menunjukkan bahwa dari 51 responden yang memiliki aktivitas fisik ringan dengan hipertensi ringan sebanyak 47 responden $(92,2 \%)$ lebih banyak jika dibandingan dengan responden yang memiliki aktivitas fisik sedang dengan hipertensi ringan sebanyak 15 responden 
$(65,2 \%)$. Dan responden yang memiliki aktivitas fisik berat dengan hipertensi ringan sebanyak 7 responden $(50,0 \%)$.

Berdasarkan hasil uji statistik yang menggunakan Uji Rank Spearman melihat signifikansi hubungan didapatkan nilai pvalue $0,000<\alpha(0,05)$ yang artinya ada hubungan

\section{PEMBAHASAN}

\section{Aktivitas Fisik}

Aktivitas fisik ringan secara independen mempengaruhi terjadinya hipertensi. Semakin ringan aktivitas fisik semakin meningkatkan risiko terjadinya hipertensi .5 Aktivitas fisik ringan adalah segala sesuatu yang berhubungan dengan menggerakkan tubuh. ${ }^{6}$ Aktivitas yang berupa gerakan atau latihan aerobik bermanfaat untuk meningkatkan dan mempertahankan kebugaran, ketahanan kardio-respirator. Aktivitas yang dilakukan berupa latihan-latihan aerobik adalah seperti berjalan, jogging, berenang, bersepeda. Latihan aerobik membuat otot-otot tubuh bekerja. ${ }^{4}$

Menurut teori lain, mengungkapkan bahwa aktivitas fisik sangat mempengaruhi stabilitas hipertensi. Pada orang yang tidak aktif melakukan kegiatan cenderung mempunyai frekuensi denyut jantung yang lebih tinggi. Hal tersebut mengakibatkan otot jantung bekerja lebih keras pada setiap kontraksi. Makin keras otot jantung dalam memompa darah, makin besar pula hipertensi yang membebankan pada dinding arteri sehingga tahanan perifer yang menyebabkan kenaikan hipertensi. Kurangnya aktivitas fisik juga dapat meningkatkan risiko kelebihan berat badan yang akan menyebabkan risiko hipertensi meningkat. ${ }^{7}$

Aktivitas fisik berpengaruh terhadap hipertensi. Semakin tinggi aktivitas fisik maka semakin kecil risiko terkena penyakit hipertensi. Seseorang dengan aktivitas ringan memiliki kecenderungan sekitar 30-50\% terkena hipertensi dibanding seseorang dengan aktivitas sedang atau berat. Aktivitas fisik yang

\section{Tingkat Hipertensi}

Hipertensi yang meningkat dapat dipengaruhi oleh gaya hidup seperti mengkonsumsi garam dapur yang berlebihan, terkadang dianggap sepele sehingga tidak memeriksakan diri ke rumah sakit/puskesmas. Hal ini karena gejala yang timbul dianggap sakit yang bermakna antara aktivitas fisik dengan tingkat hipertensi di puskesmas merdeka palembang tahun 2019. Dengan nilai correlation coefficient bernilai positif yaitu dengan hasil 0,399 maka hubungan kedua variabel searah dengan kekuatan hubungan adalah korelasi cukup.

dilakukan secara teratur dengan durasi yang tepat dapat menurunkan hipertensi. Aktivitas fisik dapat menguatkan jantung sehingga dapat memompa darah lebih baik tanpa harus mengeluarkan energi yang besar. Semakin ringan kerja jantung maka semakin sedikit tekanan darah pembuluh darah arteri sehingga mengakibatkan hipertensi menurun. Aktivitas fisik yang dapat menurunkan hipertensi tergantung pada jenis aktivitas, durasi, dan frekuensinya. ${ }^{8}$

Aktivitas fisik yang baik dan rutin akan melatih otot jantung dan tahanan perifer yang dapat mencegah hipertensi. Olahraga yang teratur dapat merangsang pelepasan hormon endorfin yang menimbulkan efek euphoria dan relaksasi otot sehingga hipertensi tidak meningkat. $^{3}$

Hasil penelitian ini sejalan dengan penelitian lain yang menyatakan bahwa ada hubungan aktivitas fisik terhadap kejadian hipertensi. Mayoritas responden yang mempunyai aktivitas fisik ringan sebanyak $68,2 \%$. Minoritas responden yang mempunyai aktivitas fisik sedang sebanyak $18,2 \%$ dan aktivitas fisik berat sebanyak $13,6 \%{ }^{4}$

Berdasarkan hasil penelitian, kajian teori, dan penelitian terkait maka peneliti berasumsi bahwa melakukan aktivitas fisik teratur seperti senam, jalan kaki, bersepeda, dan lain-lain dalam waktu 15-30 menit dapat membantu mengurangi dampak dari komplikasi hipertensi dan mengurangi peningkatan hipertensi.

kepala atau demam biasa. Adapun faktor resiko terjadinya hipertensi seperti faktor yang tidak dapat dikontrol yaitu : faktor genetik, jenis kelamin, dan individu dituntut untuk mengarahkan tenaga yang cukup besar .

Tingginya kejadian hipertensi seiring dengan bertambahnya umur yang disebabkan 
oleh perubahan struktur pada pembuluh darah besar, sehingga pembuluh darah menjadi lebih sempit dan dinding pembuluh darah menjadi kaku, sebagai akibatnya adalah meningkatnya sistolik. Sehingga dapat dikatakan bahwa usia sangat rentan terhadap risiko hipertensi yaitu semakin bertambahnya usia maka hipertensi pun akan semakin meningkat. Namun dapat dikendalikan dengan rajin berolahraga atau melakukan aktivitas fisik dan melakukan pemeriksaan tekanan darah secara rutin. ${ }^{10}$

Hasil penelitian ini sejalan dengan penelitian yang dilakukan di Puskesmas Bromo

\section{Hubungan Aktivitas Fisik dengan Tingkat Hipertensi}

Berdasarkan penelitian didapatkan hasil hubungan dari aktivitas fisik dengan tingkat hipertensi. Aktivitas fisik didefinisikan sebagai pergerakan tubuh yang dihasilkan oleh kontraksi otot rangka dan dapat meningkatkan energi. Aktivitas fisik ini mencakup berbagai macam pergerakan tubuh, mulai olahraga yang dilombakan, olahraga, hobi, atau aktivitas sehari-hari dalam rumah tangga. ${ }^{12}$

Kegiatan fisik yang dilakukan secara teratur menyebabkan perubahan-perubahan misalnya jantung akan bertambah kuat pada otot polosnya sehingga daya tampung besar dan kontruksi atau denyutannya kuat dan teratur, selain itu selastisitas pembuluh darah akan bertambah karena adanya relaksasi dan vasodilarasi sehingga timbunan lemak akan berkurang dan meningkatkan kontraksi otot dinding pembuluh darah tersebut. ${ }^{13}$

Pada penelitian di Puskesmas Merdeka Palembang Tahun 2019 bahwa kebanyakan dari penderita ini melakukan aktivitas fisik ringan. Bentuk aktivitas fisik yang biasa dilakukan responden adalah dengan kegiatan seperti olahraga secara ringan yang sebenernya merupakan kegiatan sehari-hari yang biasa dilakukan dirumah seperti menyapu lantai, berjalan kaki, bersepeda, dan lain-lain untuk mengurangi peningkatan tekanan darah.

Hal ini sejalan dengan penelitian lain yang menyatakan bahwa ada hubungan antara aktivitas fisik dengan tingkat hipertensi. ${ }^{14}$ Selain itu, aktivitas fisik berhubungan dengan tekanan darah pada masyarakat penderita hipertensi di wilayah Tlogosuryo hipertensi di wilayah Tlogosuryo RT/RW 01/02, Kelurahan Tlogomas Kecamatan Lowokwaru Kota Malang, dengan nilai korelasi negatif yang
Medan menyatakan bahwa ada hubungan antara aktivitas fisik dengan tingkat hipertensi. Mayoritas responden dengan hipertensi ringan $66,7 \%{ }^{3}$ Minoritas responden dengan hipertensi sedang $16,7 \%$ dan responden dengan hipertensi berat $16,6 \%{ }^{11}$ Berdasarkan hasil penelitian, kajian teori, dan penelitian terkait maka peneliti menyimpulkan bahwa hipertensi dapat di kontrol kembali dengan melakukan pemeriksaan setiap bulan ke pelayanan kesehatan dan mengkonsumsi obatnya secara teratur serta dapat mengontrol emosi.

dimana kurangnya aktivitas fisik berdampak pada tingginya tekanan darah. ${ }^{15}$ Penelitian ini juga sejalan dengan penelitian lain yang menyatakan bahwa ada hubungan yang signifikan antara aktivitas fisik dengan derajat hipertensi pada pasien rawat jalan di wilayah kerja Puskesmas Tagulandang. ${ }^{16}$

Pentingnya berolaraga dan bergerak badan demi terbentuknya otot-otot jantung yang lebih tangguh. Jantung yang tangguh tetap kuat memompa darah kendati menghadapi rintangan pipa pembuluh darah yang sudah tidak utuh lagi. Jantung yang terlatih sejak usia muda ototnya lebih tebal dan kuat di banding yang tidak terlatih. ${ }^{17}$ Hasil studi lain yang menyatakan bahwa ada hubungan antara aktivitas fisik dengan kejadian hipertensi. ${ }^{18}$ Kondisi tekanan darah yang tinggi menambah beban jantung dan arteri. Jantung harus bekerja lebih keras dari normal yang ditentukannya. ${ }^{19}$

Aktivitas fisik yang teratur membantu meningkatkan efisiensi jantung secara keseluruhan. Mereka yang secara fisik aktif umumnya mempunyai tekanan darah yang lebih rendah dan lebih jarang terkena tekanan darah tinggi. Mereka yang secara fisik aktif cenderung untuk mempunyai fungsi otot dan sendi yang lebih baik, karena organ-organ demikian lebih kuat dan lebih lentur. Aktivitas yang berupa gerakan atau latihan aerobik bermanfaat untuk meningkatkan dan mempertahankan kebugaran, ketahanan kardio-respirator. ${ }^{20}$

Dari penjelasan diatas maka peneliti berasumsi bahwa melakukan aktivitas fisik minimal 15-30 menit/hari dapat mengurangi dampak terjadinya peningkatan hipertensi dalam tubuh serta menghasilkan gerakan yang baik yang dapat memelihara keseimbangan dalam tubuh. 


\section{KESIMPULAN DAN SARAN}

Sebagian responden yang hipertensi melakukan aktivitas fisik ringan, bentuk aktivitas fisik yang biasa dilakukan seperti olahraga secara ringan yang merupakan kegiatan sehari-hari yang biasa dilakukan dirumah seperti menyapu lantai, berjalan kaki,

\section{UCAPAN TERIMA KASIH}

Peneliti pada kesempatan ini ingin mengucapkan terima kasih yang sebesarbesarnya kepada Bapak Dr.dr.H.Ibrahim Edy Sapada, M.Kes selaku Ketua STIK Siti Khadijah, Ibu Ns. Mardiah, S.Kep.,M.Kes

\section{DAFTAR PUSTAKA}

1. Kemenkes RI. 2014. Profil Kesehatan Indonesia 2014. Jakarta: Kementerian Kesehatan RI.

2. Profil Dinas Kesehatan Sumatera Selatan. 2017.

3. Pranama. 2016. Hubungan Aktivitas Fisik dengan Tingkat Hipertensi di Wilayah Kerja Puskesmas Demak II Tahun 2016. Skripsi. Sarjana Kesehatan Masyarakatat. Fakultas Kesehatan Masyarakat. Universitas Muhammadyah Semarang. Diakses 15 Agustus 2019

4. Harahap. 2017. Hubungan Aktivitas Fisik dengan Tingkat Hipertensi di Wilayah Kerja Puskesmas Bromo. Medan. Jurnal Muara Sains, Teknologi, Kedokteran, dan Ilmu Kesehatan, 1(2):68-73.

5. Anggara \& Prayitno, N. (2013). Faktorfaktor yang Berhubungan dengan Tekanan Darah di Puskesmas Telaga Murni Cikalang Barat. Jurnal Ilmiah Kesehatan, 15(1): 20-25

6. Kokkinos PF, et al, 2009. Physical Activity in The Prevention and Management of High Blood Pressure. Hellenic J Cardiologym,

7. Hasanudin, Ardiyani., Mariah Vita., \& Perwiraningtyas Pertiwi, 2018. Hubungan Aktivitas Fisik Dengan Tekanan Darah Pada Masyarakat Penderita Hipertensi Di Wilayah Tlogosuryo Kelurahan Tlogomas Kecamatan Lowokwaru Kota Malang. Jurnal Universitas Tribhuwana Tunggadewi Malang. 3 (1). bersepeda dan lain-lain untuk mengurangi peningkatan tekanan darah.

Kepada petugas puskesmas agar selalu memberikan pendidikan kesehatan kepada responden yang hipertensi baik secara personal maupun berkelompok.

Selaku Ketua Prodi DIII Keperawatan, Ibu Yunilda Rosa, M.Si selaku Ketua Lembaga Penelitian STIK Siti Khadijah, serta temanteman dosen STIK Siti Khadijah yang telah membantu dalam penelitian ini.

8. Sutanto. Cekal Penyakit Modern Hipertensi, Stroke, Jantung, Kolesterol, dan Diabetes. Yogyakarta: C.V Andi Offset; 2010

9. World Health Organization. 2010. Global Report Diabetes. Diakses 13 Mei 2019.

10. Triyanto, Endang. 2014. Pelayanan Keperawatan bagi Penderita Hipertensi secara Terpadu.Yogyakarta : Graha Ilmu.

11. Paruntu. 2015. Hubungan Aktivitas Fisik, Status Gizi Dan Hipertensi Pada Pegawai Di Wilayah Kecamatan Tomohon Utara. GIZIDO, 7(1).

12. Sutomo, B. 2009. Menu Sehat Penakluk Hipertensi. Jakarta: DeMedika Pustaka.

13. Budi, Ls., Sulchan, HM., Wardani, RS. 2011. Beberapa Faktor yang Berhubungan dengan Tekanan Darah pada Usia Lanjut di RW VIII Kelurahan Krobokan Kecamatan Semarang Barat Kota Semarang. Fakultas Kesehatan Masyarakat Universitas Muhammadiyah Semarang. Diakses $1 \mathrm{Mei}$ 2019.

14. Maksuk M. Analisis Faktor Risiko Penyakit Hipertensi Pada Masyarakat Di Kecamatan Kemuning Kota Palembang Tahun 2012. JPP (Jurnal Kesehat Poltekkes Palembang). 2012;1(10).

15. Hasanudin, dkk. 2018. Hubungan Aktivitas Fisik dengan Tekanan Darah pada Msyarakat Penderita Hipertensi di Wilayah Tlogosuryo Kelurahan Tlogomas Kecamatan Lowokwaru Kota Malang. Jurnal Nursing News, 3 (1). 2018. 
16. Karim, Nurafni. 2018. Hubungan Aktivitas Fisik dengan Derajat Hipertensi pada Pasien Rawat Jalan di Wilayah Kerja Puskesmas Tagulandang Kabupaten Sitaro. E-Journal Keperawatan, 6(1).

17. Welis W \& Rifki M, 2013. Gizi untuk Aktivitas Fisik dan Kebugaran. Jakarta : Pustaka Pelajar
18. Muliyati H., Syam A., \& Sirajuddin S. 2011. Hubungan Pola Konsumsi Natrium dan Kalium Serta Aktivitas Fisik dengan Kejadian Hipertensi pada Pasien Rawat Jlkan di RSUP DR. Wahidin Sudirohusodo Makasar. Media Gizi Masyarakat, 1 (1).

19. Dalimartha S, dkk. 2008. Care Your Self Hipertensi. Depok : Penebar Plus

20. Giam CK. 2000. Ilmu Kedokteran Olahraga. Jakarta : Binarupa Aksara 